\title{
Determinant of Youth Unemployment and Consequence: A Case Study of Mirpurkhas Region
}

\author{
Dileep Kumar $^{1 *} \quad$ Kumar Jai $^{2} \quad$ Kumari Joti ${ }^{3}$ \\ 1.Institute of Business Administration, University of Sindh, Jamshoro, Pakistan \\ 2.School of International \& Public Affairs, Jilin University, Changchun 130012, China \\ 3.Business School, Sichuan University, Chengdu 610065, China
}

\begin{abstract}
In the vast ocean of the $195^{\text {th }}$ countries, Pakistan lies under the band of developing countries that are still fighting in this global world for survival for being a developing country. Yet, it has been facing a massive crisis, including unemployment in Pakistan, since its emergence. Unemployment, mainly youth unemployment, is a big issue facing countries globally in the recent Covid pandemic. Youth unemployment is also responsible for the prevalence of crime and violence where employment opportunities are limited. In Pakistan, unemployment has been one of the most persistent contentious economic complexities. There are so many hurdles in the way of young people during the search for suitable jobs. The present study is designed to explore youth unemployment in the Mirpurkhas region. A large number of the youth population of Pakistan is living in rural areas. The government has partially failed in providing the best development opportunities. The growth rate is not substantial enough to create job opportunities; this situation creates frustration in youth, leading to conflict, unrest, and violence. Nowadays, Youth unemployment is a significant problem, so it is pertinent to find out their causes. A sample of 400 respondents was taken from random sampling, mainly focus on the close-ended questionnaire. Further, the raw data is analyzed by SPSS software through which different techniques are performed like Multiple linear regression, ANOVA, and correlation. The result shows that inadequate quality education, lack of skills/experience, improper government regulation, economic instability significantly affect youth unemployment. The present youth group is quite significant. The long-term viewpoint for youth unemployment is relatively tremendous. There is a sturdy case for policymakers currently to handle this problem that the present group is having in finding access. The result can be used to mitigate the issue of youth unemployment in Mirpurkhas region.
\end{abstract}

Keywords: International labour organization, International monetary fund, foreign direct investment, youth unemployment

DOI: $10.7176 / \mathrm{EJBM} / 13-18-08$

Publication date:September $30^{\text {th }} 2021$

\section{Introduction}

The COVID-19 pandemic will eventually go away by the vacation. The consequences for a job and life hoods across the world will be felt for many years to come; this is the main takeout from the latest world economic viewpoint released by an international monetary fund (IMF) in recently October. The pandemic had and will continue to have especially severe effects on the most economically vulnerable people, mainly informally employed women and younger workforces. The burden of the crisis, the report says, has fallen unevenly across the economic domain: while the shocks of the recession have been less grievous for those who can work from home, the workers that are employed in industries such as accommodation and food services, transportation, retail and wholesale have been especially hard hit. Furthermore, the pandemic exacerbated earlier poverty and income inequality trends, which were already rising in many advanced, emerging, and developing economies. Lockdowns and school closures cast a long shadow on millions of children's prospects to a trove of academic studies that have demonstrated lower and interrupted lifetime schooling associated with lower lifetime income and earnings paths. The toll of COVID-19, quite simply, threatens to fully undo decades of progress and push tens of millions of people into job insecurity, not just today but tomorrow as well. With the onset of the COVID19 pandemics, unemployment rates have soared, and most states have announced hospitalization and residence (Inanc, 2020). Unemployment is one of the biggest problems for today's youth because they are studying to be the breadwinner of the family. Still, it is hard to have reliable and perfect jobs due to the country's economic problem (Bell \& Blanchflower, 2010). Unemployed is considered the burden on the country's economic resources as it lowest the social status of the person and its family (A. Hafeez et al., 2020). The unemployment problems begin when abled individuals fall short of vacant jobs; however, the nature and extent of unemployment varies across the regions and states, while lack of technical skills and working experience are regarded as the primary source of furthering unemployment concern (Mehmood et al., 2021). World Bank defines as youth under the age of 15-24 years old who are without work but currently available for work and sought in the recent past. Youth unemployment is one of the critical global labor market challenges of today. Youths are considered as the essential resources of any country; they are energetic, courageous, and qualified 
they can bring economic development if they are appropriately utilized (Batu, 2016). According to ILO report, it states that about one-fifth of the world's population is unemployed. Although economic recovery unemployment rate is still very high. The possibility that youths are more likely to be unemployed than adults around the world (Global Employment Trends for Youth 2020)

The COVID-19 crisis has mostly affected worldwide, hurting young people more than any other age group. Globally, Youth unemployment fell by 8.7 percent, while the adult employment rate fell by 3.7 percent, mainly in middle-income countries. The employment gap caused by the global crisis will reach 75 million in 2021, and it is estimated that by 2022, the number of unemployed persons globally will reach 205 million. The reduction in jobs and working hours has led to a decline in income and an expected increase in poverty (Outlook, 2021). Youth bring with themselves different resources are an inevitable part of our educational and vocational concerns. It is a matter of an important priority area on the political agenda of several states and bilateral or multilateral development agencies. The rise in the number of young people in tertiary educational institutions is a definite improvement. Still, labor markets in most nations are not currently enjoying the same development benefits (Awogbenle\& Iwuamadi, 2010). However, formal education does not always guarantee employment (Prof \& Karymshakov, 2017). In Pakistan today, whereas one might expect the young populace's potential to be outfitted for higher profitability and financial development, the circumstance is inverse since the adolescent rate is high. Our country is sitting on a statistical time bomb (E. Hafeez, 2018). The literacy rate of countries that provide jobs, such as Pakistan, is not satisfactory to providing job opportunities, which is an uphill task. It is a truth that younger people's services improve the countrywide economy by growing over the aggregated required between buildings concerning capital (Msigwa \& Kipesha, 2013). As census result of 2017 shows that Pakistan becomes the $5^{\text {th }}$ most populous nation in the world with around 208 million people. Much beyond what has been projected over the year by policymakers. About 60 percent of the country's population belongs to the youth under age 30, but job opportunities seem to be far too few. In this regard, unemployment is likely produced. Business activities have been the victim of power outages, and the country's attractive policies for firms led to the closure of business, hence the loss of jobs. The government has not created job opportunities through an extensive industrialization process, promoting small-scale firms and infrastructure development. In Pakistan, the tendency of both genders toward education is very high. Educated young fellows, both male and female, drop their resumes in different governmental and non-governmental organizations but must be content with the job marketplace's poor response. Pakistan has a strong feudal political system; in this system, deep inroads have been made by landed people and business tycoons; these so-called political leaders strongly impact the social and governmental institutions they use for their selfish motives. It simply means only those who can get jobs easily, who have a political approach. According to the PIDE study, around 18.5 million people ( 30 percent of the employed labor force) who were part of vulnerable employment were laid off in a complete shutdown. However, over 12 million people (20 percent of the employed labor force) have loosed their jobs even with moderate restrictions. Within the vulnerable employment, the bulk of the layoffs would comprise daily-wage workers and those who work on a piece-rate basis. while Formal-sector workers are also at risk. Most of the population of Pakistan continues to be residing in rural areas. The youth from those regions often face trouble finding employment once they selected to live in their home areas. Work availability is constrained, and absences of opportunity are raising the unemployment rate. Consistent with the Economic survey $(2014,2015)$ and labor force survey (2017-2018), Pakistan has urban unemployment of $9 \%$, and the rural unemployment rate is $14 \%$, respectively(IMRAN et al., 2020). The overwhelming majority of the youth of Mirpurkhas, who has acquired college or university education, has this inbuilt notion that jobs in both the private and public sectors cannot be led without powerful reference. They assume that the jobs in the public sector are available only on political affiliation and strong references with money. However, the public sector is trying to reduce unemployment by creating jobs in different sectors and making policies, but they are only implemented in documents. Mostly observed that youth living in rural areas do not want to leave their homes, and if they migrate into urban, they feel homesick and insecure because of the language difference between Urdu and Sindhi. Young fellows, especially females, prefer jobs in the education sector because they feel insecure in different sectors like banks and NGOs, and in that way, they are jobless. Some youths are working at meager wages because they are either fresh graduates or have no other jobs. The purpose of this study is to examine the factor associated with youth unemployment in Mirpurkhas region. The conceptual framework was developed in this paper that was based on work-related factors between youth unemployment and its consequences. The main thirst of this paper is to classify the main factor that affects youth issues related to jobs in the Mirpurkhas region. 


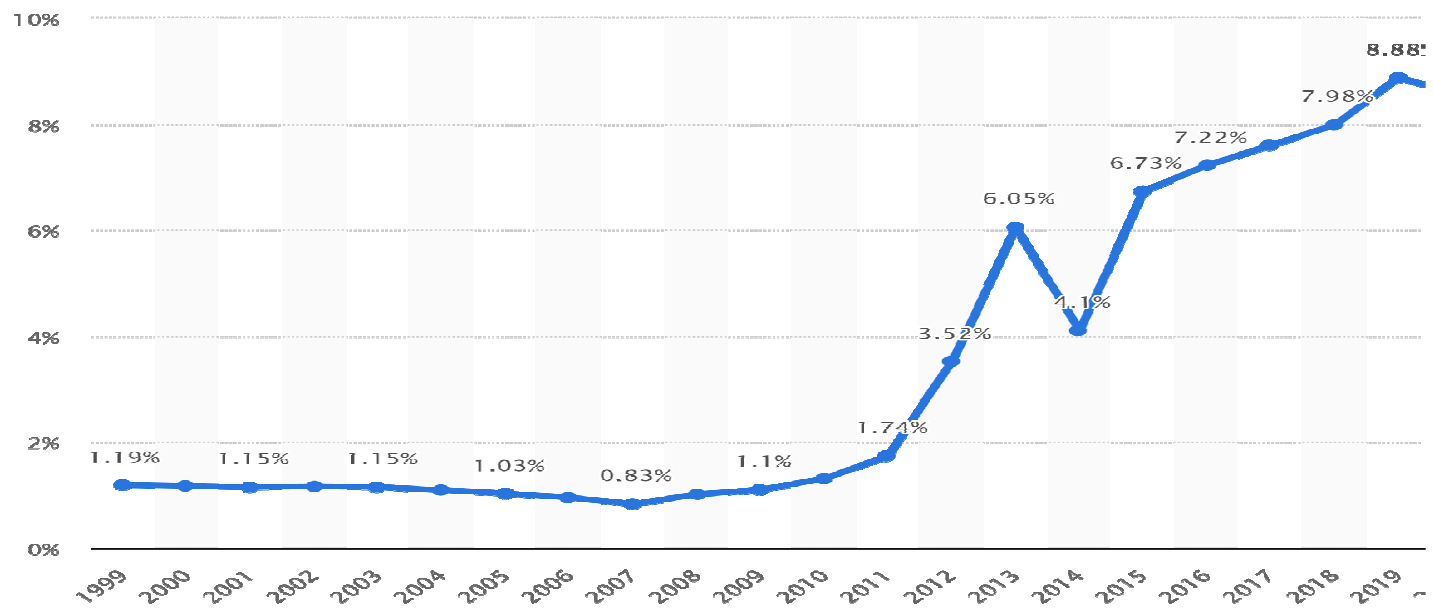

(Source world bank)

Figure 1Graph of Youth unemployment rate from 1999 to 2020

Logically high level of youth unemployment shows that the failure of the country's economy to use its labor force effectively. The statistic shows the youth unemployment rate in Pakistan from 1999 and 2020. According to the source, the data are ILO estimates. In 2020, the estimated youth unemployment rate in Pakistan was 8.54 percent.

\section{Literature Review}

A large amount of literature is available in this connection which allows us to scrutinize the unique element of youth unemployment as observed in the study. One belief is that the younger generation is probably more prompt on quitting their jobs in the beginning periods of their professional career in search of a good one (Maqbool et al., 2013). As it is known, young people are more susceptible to changes throughout the business cycle (Duran, 2016). As a life-threatening event, youth unemployment may lead to other unfavourable market factors such as lack of long-term job security, reduced job mobility, and inability to occupy an active position in society (Doku et al., 2018). Pakistan is one of the youngest countries globally and represents $64 \%$ of the world's population (Hyder, 2019). The risk of unemployment for the young is generally greater than for adults for many distinct reasons. These include the absence of work experience, incomplete education, nature of the contractual relationship, and fewer contracts for available jobs. There may be a difficulty in transition from schooling to the world of work due to skill mismatch. All this could propose long-lasting terrible efforts for the younger population or indirect costs for unemployed individuals in the form of the so-called "scarring effect" (Eichhorst et al., 2013). Unemployment is not just a social means; it brings dissatisfaction and promotes harmful activities among youth like terrorism, burglary, and street crimes (Imtiaz et al., 2020). (Ali et al., 2016) identified that the main reason for youth unemployment in the formal sector was lacking required qualifications and training. The other reason behind youth unemployment was lack of work experience, non availability of job information, and inability to bear the cost of getting a job. (Abera, 2011) conducted an empirical study about the problem of youth Besides they stated that the main problem of the unemployed among young people is the difficulty of finding work. Unfortunately, lack of income, lack of experience, a problem in social circles, loss of confidence are the broad reasons. Youth unemployment is giving rise to much social havoc; social delinquencies are increasing rapidly. Because of unemployment, youth is bound to do any work to earn money, together with unlawful activities like robbery, prohibited drug trade, and the increase of terrorism in the country, which has been the cause of instability and challenging economic conditions. (Asalfew, 2011) explored an empirical study about demographic and socio-economic determinants of youth unemployment and asserted the main factors are is lower education level, limited social network, and mismatch of skills. (Baah-Boateng, 2013) studied the determinants of youth unemployment in Ghana. By analysis Confirmed that residents of urban areas and the youth are easy victims of unemployment. Their reasons are found in education and gender inequalities.(Bayraktar s, 2013) explaining cross-national variation in youth unemployed European and they find that lack of vocational education and vocational training is the main reason for unemployment.

Further, they emphasize that vocational educational institutes should take bold action by providing vocational training to reduce unemployment. (Farooq, 2011) demonstrated job gaps in Pakistan form three factors: education categories, a field of education, and skills. They suggest that either educational institution produces graduates not relevant to market demand or develops insufficient skills among students comparable to market requirement. (Gebretasdik, 2016) studied the causes of educated youth unemployment and its socioeconomic effect indicated that significant causes of youth unemployment are developing country's economic performance, state failure in creating adequate jobs, skills mismatch, lack of entrepreneurship skill, and attitude 
of job selection. Recently identified lack of relevant skills as one major cause of the high rate of youth unemployment. As noted above, a second report ILO (2013), has also highlighted that ongoing global (ILO, 2012). (Jabeen, 2011)explained that the mismatch between graduating university scholar's notion perception and employee expectation concerning employability skills. The study found significant differences between employee expectation and student perception through necessary skills, discipline, encouraging attitude, personality, time management, and oral communication. These are the skills highly ranked by employees that are necessary ((Mpanju, 2012)worked on the employment effect of foreign direct investment in South Africa, exploring that the unemployment rate was more significant in rural areas than in the urban areas of Tanzania. They derive that being a graduate without skills made approximately 23 percent much less likely to hire than being employed. It means that graduates without abilities are more likely to be unemployed than skilled employed, so skill is essential in reducing unemployment. (Mahmood et al., 2014) empirically identifies the factors involved in the unemployment rate in Peshawar, Pakistan.

The final model concludes that the most critical determinants of unemployment are the more increasing rate of the population, lack of resources, and non-coordination among education and job opportunities, red ribbon, and role of attitude in getting a high-level job. (Okojie, 2011) worked on Formate evaluation of United Nations girls' education, identified that the low standard of education and the rapid expansion of the educational system are the leading causes of youth unemployment in Nigeria. (Blom \& Saeki, 2011) studied the skill gap for Indian engineers through a survey. Their research classified all skills by factors in three skills groups: core employability skills, communication skills, and professional skills. The results proved that overall, employees were dissatisfied with the quality of engineering graduates. They conclude that education in the state focuses on enhancing soft skills(Cheema \& Atta, 2014)studied on empirical estimation of Okun's law in Pakistan. Their results found that people with no employment because the economy is in recession do not have education and skills. Job vacancies are not available if available are very limited. People are also unaware of vacant jobs. Job seekers cannot find a job according to their wishes because of the unavailability of proper guidance and career counseling. The growth rate of youth unemployment in Pakistan is the consequence of the sudden increase in population, meager law and order situation, worse economic conditions, corruption, violence, and an imperfect education system (Ahmad, 2017). Pakistan allows 1.5 to 2.0 percent only of GDP on education, so there is a lack of facilities in educational universities. In that way, students are not adequately trained according to market demand and can get a proper job(Nadia Naviwala 2016). In Pakistan, unemployment is growing more in rural areas, and one-third of the population is living. They have no facilities like primary health care, education, job opportunities, social services, and many other problems due to unemployment rising day by day. Every year, many students in different disciplines pass from Pakistani universities, but job opportunities seem too few to fewer (Saleem, 2018). In the Government sector, there are meager chances of employment on a merit basis, there are. Most vaccines are packed through personal contacts of the candidate within the firms, compromising the rules of equitable and fair chance and the quality of recruitment. There is no guarantee of a job for ordinary students after completing degrees and qualification professionals from the universities in those circumstances. Mainly the most critical problem of Pakistan, Unemployment that holds a central place, and it is far increasing with each passing day and is affecting the youth by pushing them into the depth of sadness. People throughout the country are suffering the problem and are helpless to find a way out of this dilemma. The literature on youth unemployment reveals mixed results. In this result, we examine that the key factors that affect youth unemployment in the Mirpurkhas region.

\subsection{Conceptual Framework}

Now a day Unemployment is the main problem in developing in addition to evolved international locations. Pakistan is among those countries where unemployment is a lethal threat in urban and rural areas. In Pakistan, variation in the unemployment rate with younger is much higher that is the age between $15-24$ is $11.5 \%$. In terms of education level, it is also higher that is $7.5 \%$ while the illiterate person unemployment ratio is $3.2 \%$. The labor market's enormous failure to absorb human capital reflects the supply side problem (dr Pasha, 2021). The network of young people is usually limited, which depends mainly on the social status of their parents, so they have limited access to job information and social impact (Hällsten et al., 2016). This study is concerned with youth unemployment; many factors affect youth unemployment. Among them, we examined seven independent factors for youth unemployment. The selected elements are inadequacy of quality education, lack of experience, lack of skills, economic instability, improper government regulation, lack of opportunity. 


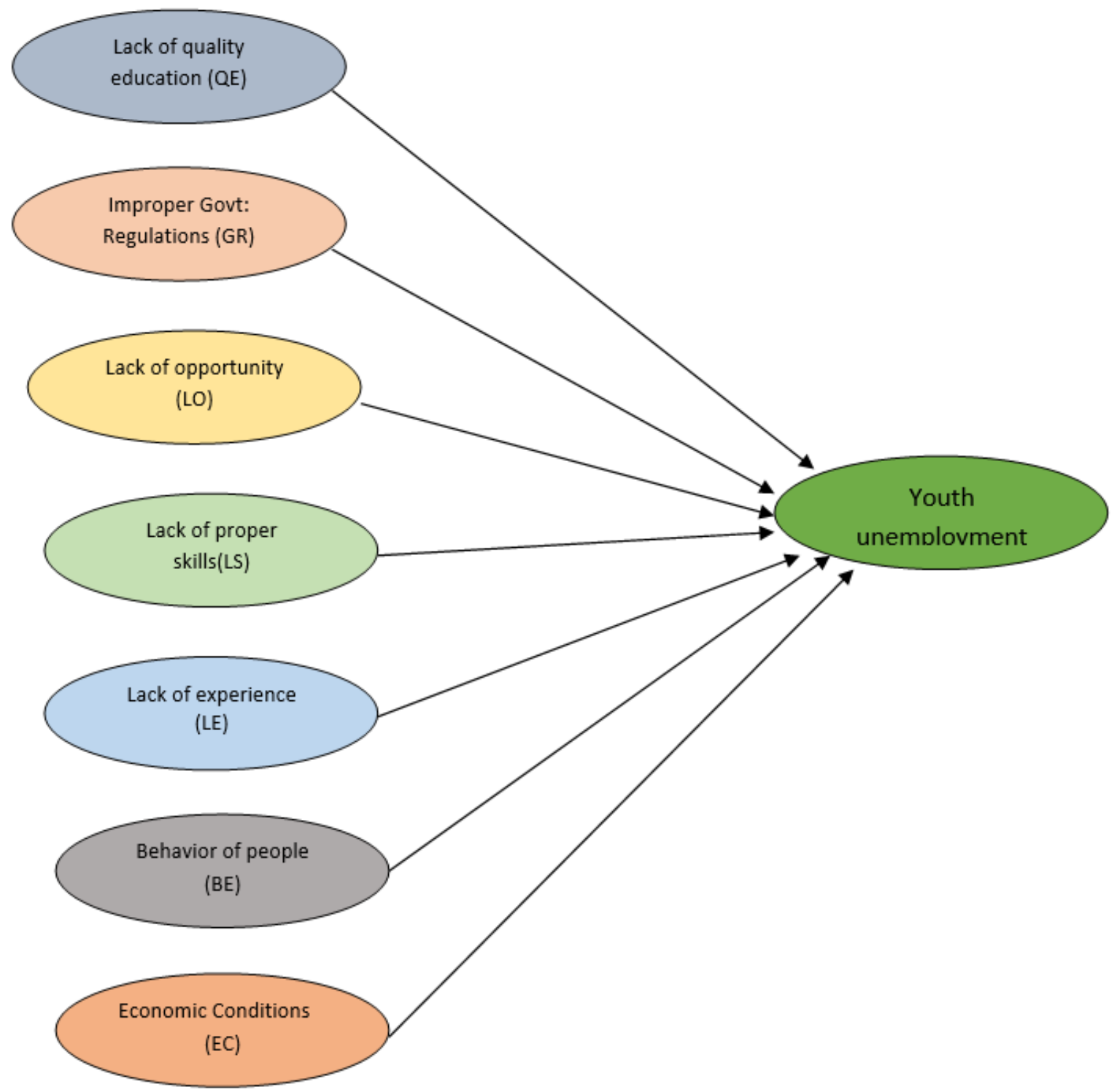

Figure 2 Conceptual framework (Source: Author)

Figure 2 shows the conceptual model of the determinant of youth unemployment. In which, it is identified that seven dimensions that lack of quality education, improper government regulation, lack of opportunity, lack of skills, lack of experience, the behavior of people, and economic condition affect youth unemployment in the Mirpurkhas region. Some studies show a positive link between these factors. At the same time, previous studies showed the link of other factors like GDP, FDI, economic recession, and terrorism.

\section{Methodology}

This study is conducted among the youth who are living in the different areas of the Mirpurkhas region. The purpose is to observe the relationship between dependent and independent variable in the Mirpurkhas region. The data is collected from the respondents under the age of 15-24, primarily fresh graduates and jobless. Some factors such as population size, precision, confidence time, and cost constraint were considered for selecting the sample. Four hundred questionnaires were distributed based on a non-probability sampling technique. The respondents were from different faculties and a mixture of fresh graduates and other jobless.

\subsection{Measurement Instrument}

In this study, a close-ended questionnaire on youth unemployment was developed using a 7-point Likert scale. The developed questionnaire was based on the literature on youth unemployment to suit the local context. Here forty questions including 7 items variables were included youth unemployment. The focus of the survey questionnaire was to assess the sentiment or feeling of the youth population concerning their current future employment prospect (Higgs \& Cherry, 2009). The questionnaire was split into two segments demographic and 
youth unemployment.

\subsection{Statistical Tools for Data Analysis}

This study consists of two analytical steps: 1 compile the demographic data of 400 respondents, including age, gender, marital status, and education level, to determine the most significant factor in youth unemployment. In addition, these two steps Pearson product-moment correlation were tested between the elements to determine which of the high correlation with the dependent variable. Finally, a multiple regression was run to examine which extracted factors substantially impact youth unemployment in the Mirpurkhas region. These analyses were computed by using the software SPSS version 20.0 .

\subsection{Ethical Consideration}

Ethical consideration is a crucial part of research that will emerge the plan of study; Ethics refers to the application behavior concerning the right of those who are part of your research are influenced by it the participant was informed of the purpose of the study assured of confidentiality. In turn, they provide written consent.

\section{Data Analysis}

The demographic result shows that nearly $62 \%(n=400)$ of the participant are male while $38 \%(n=400)$ were female respondent in relation to occupation $47 \%(\mathrm{n}=189)$ are part time employed, about $20 \%(\mathrm{n}=81)$ are selfemployed and $32 \%(n=129)$. In contrast with education of the respondent about $3.5 \%(n=14)$ are intermediate, $32 \%(n=127)$ are undergraduate, master level respondents are 53\% $(n=213)$ and $11.5 \%$ are MPhil and PhDs in relation with martial status about $51 \%(n=204)$ are married and $49 \%(n=196)$ are single. Cronbach's coefficient for each dimension of the survey ranged from 0.614 to 0.877 (typically 0.6 and above is acceptable) which indicates the internal consistency of each factor.

Table 1 Demographic Profile of the Respondents

\begin{tabular}{|l|l|l|}
\hline Respondents Description & Frequency & Percentage \\
\hline Gender & & \\
Male & 247 & 62 \\
Female & 153 & 38 \\
\hline Age & & \\
Below 21 Years & 112 & 28 \\
21-30 Years & 206 & 51 \\
30-40 Years & 72 & 18 \\
40-50 Years & 10 & 2.5 \\
\hline Marital Status & & \\
Married & 204 & 51 \\
Unmarried & 196 & 49 \\
\hline Qualification & & \\
Intermediate & 14 & 4 \\
Undergraduate & 127 & 35 \\
Masters & 213 & 53 \\
MPhil/PHD & 46 & 12 \\
\hline Occupation & & \\
Part-time employed & 189 & 47 \\
Self-employed & 81 & 20 \\
Student & 129 & 33 \\
\hline
\end{tabular}

Table 2 Regression Analysis

\begin{tabular}{|c|c|c|c|c|c|}
\hline \multicolumn{6}{|c|}{ Model Summary } \\
\hline Model & $\mathbf{R}$ & $\begin{array}{l}\mathbf{R} \\
\text { Square }\end{array}$ & $\begin{array}{l}\text { Adjusted } \\
\text { R Square }\end{array}$ & Std. Error of the Estimate & Durbin-Watson \\
\hline 1 & $.890^{\mathrm{a}}$ & .717 & .735 & .48917 & 1.743 \\
\hline \multicolumn{6}{|c|}{$\begin{array}{l}\text { a. Predictors: (Constant), Economic condition, lack of proper skills, lack of Experience, Lack of quality } \\
\text { Education, improper Government Regulation, Lack of Opportunity, Behavior of people } \\
\text { b. Dependent variable: youth unemployment }\end{array}$} \\
\hline
\end{tabular}

As shown in table of Model summary of regression, the independent variable explains 33\% variation in the independent variable in the model $\mathrm{R}$ square is Nearly $72 \%$. The value of Durbin Watson is 1.743 shows, autocorrelation exists in the model, although the Adjusted square is statically $73.5 \%$ is statistically significant. 
Table 3 ANOVA Analysis

\begin{tabular}{|c|c|c|c|c|c|c|}
\hline \multicolumn{7}{|c|}{ NOVA } \\
\hline & & Sum of Squares & Df & Mean Square & $\mathbf{F}$ & Sig. \\
\hline \multirow[t]{3}{*}{1} & Regression & 60.535 & 7 & 12.505 & 83.745 & $.000^{\mathrm{b}}$ \\
\hline & Residual & 39.369 & 232 & .171 & & \\
\hline & Total & 99.904 & 239 & & & \\
\hline
\end{tabular}

As per the Annova table show, the $\mathrm{F}$ ratio of 83.74 values ( $\mathrm{P}$ less than 0.01 ) indicates the regression of the dependent variable it signifies that the dependent variable youth unemployment is more consistent.

\section{Discussion and Conculsion}

Youth is a great asset of any country. The bright future of any nation depends upon the youth. Youth unemployment is one of the most severe socioeconomic problems in the world. The problem is so powerful among young people in countries of the world, particularly in the developing countries. The high youth unemployment rate indicates a failure to utilize human capital, essential for economic development. Though youth are indispensable assets for economic prosperity and social security, they have been detached from the labor market. As a result, their energy and talent have been wasted, their contribution to development is not afforded a rightful place due to social-economic and demographic factors. Currently, addressing the youth unemployment problem has become a significant development and political agenda of several states. The issue of youth unemployment is the outcome of different socio-economic and demographic factors. As indicated in the theoretical approach and emphasized in the finding, demographic factors play a decisive role in determining youth unemployment. The availability of inadequate business advisory services to young people significantly influences the employment status of youth. Based on this finding, it is possible to conclude that the relative risk of unemployment is higher for youth who have no access to the service. Besides, preferring jobs in the formal sector also affects the unemployment status of youth. Thus, youths who like paid employment in the traditional sectors have a higher likelihood of unemployment. Degree holders educated youth people are unable to find jobs. Educated youths get insufficient job opportunities, deficient economic plans, nepotism, and an inadequate education system. The regional issues further inflamed the already dangerous status of unemployment in Sindh. The result also showed that "single "people are more unemployed than married ones because the liabilities make it necessary for them to avail job opportunities at whatever remuneration it is available. Rural people are much unemployed than urban.

In the urban field, some industries absorb the youth, while this type of facility is not available in rural areas. On the other hand, new technologies have delivered a new consignment of machines and plants, reducing the demand for manual work. In this quite upsetting atmosphere, the worst sufferers are knowledgeable teenagers who indeed excel than their formal education counterparts. In a nutshell, youth unemployment in Pakistan is customary because there is no proper counseling of future dimensions. A large part of the populace has excessive resources to live a luxurious life. The rest are subjugated badly as their incomes are depressed. The reason is the lack of opportunity to be employed or if at all they get it. The wages are too low to make two ends meet the situation. The passionate youth who steps in market with devotion to thrive but mostly in despair and with devoid potential. The flexible wage structure in Pakistan minimum wage legal guideline poor tracking of demand and supply of hard work pressure are contributing in aggressive condition. Among the various channels used by unemployment to search for a job, data do not indicate the stark difference between rural and urban divide except in the use of "Advertisement" mode, which is much lower of the rural group. Further, the result of this study reveals that the various determinants of youth unemployment are the lack of quality education, lack of experience, improper skills, improper government regulation, economic condition. Besides that, the Youth unemployment youths of Mirpurkhas are educated less educated. Still, they have no technical expertise. The other main factor explored is the absence of the industrial sector, and low paid practice to workers. Most jobs are on nepotism and favoritism basis and obsolete infrastructural system in Mirpurkhas, Sindh Pakistan.

\section{Implication of study}

Studying youth and issues related to Youth unemployment is a challenging assignment. An unexpectedly changing and closely connected world across disciplinary methods is needed to unfold many layers of complicated and intertwined phenomena. As the current study has done, examining youth unemployment in a regional context deepens our expertise; few prior types of research have had such a focus. More ever, this investigation has direct implications for regions' public policy decisions, specifically in the areas of economic, education, and youth development policy.

\section{Limitation and Future Research Recommendation}

The research study contributes to an understanding of youth unemployment and consequences a case study of 
Mirpurkhas. However, some limitations. Mirpurkhas Region culture is also a limitation in this regard because many non response or unwillingness by the respondent to release all the necessary information about the determinants of youth unemployment. Youth do not feel comfortable answering the Questioner and mostly manipulate the data resulting in false results for the researchers. However, this will highlight some significant impacts on youth unemployment. This research was based on "Youth Unemployment: causes and consequences of unemployment in Mirpurkhas." The study concludes that there is a positive impact of independent variables (Inadequate quality of education, inappropriate regulation of government sector, lack of opportunity, behavior of people, lack of proper skills, lack of experience, and economic condition) on Youth unemployment. Research shows that these independent variables are the causes and consequences of youth unemployment. It could be better if we study more factors that create youth unemployment. Future research can be done by using more factors and focusing on more developed cities and cultures.

\section{References}

Abera, A. (2011). Demographic and Socio-Economic Determinants of Youth Unemployment in Debere Birhan Town, North Showa Administrative Zone, Amhara National Regional State. Addis Ababa University.

Ahmad, Z. (2017). An Analysis of the Causes and Consequences of Unemployment in District Peshawar. 79210.

Ali, S., Dean, A., \& Jabeen, U. A. (2016). YOUTH UNEMPLOYMENT AND THE EFFECTS OF REGIONAL. $4(8), 82-92$.

Awogbenle, A. C., \& Iwuamadi, K. C. (2010). Youth unemployment: Entrepreneurship development programme as an intervention mechanism. African Journal of Business Management, 4(6), 831-835.

Baah-Boateng, W. (2013). Determinants of unemployment in Ghana. African Development Review, 25(4), 385399.

Batu, M. M. (2016). Determinants of youth unemployment in urban areas of Ethiopia. International Journal of Scientific and Research Publications, 6(5), 343-350.

Bell, D. N. F., \& Blanchflower, D. G. (2010). Youth unemployment: déjà vu?

Blom, A., \& Saeki, H. (2011). Employability and skill set of newly graduated engineers in India. World Bank Policy Research Working Paper, 5640.

Cheema, A. R., \& Atta, A. (2014). Economic determinants of unemployment in Pakistan: Co-integration analysis. International Journal of Business and Social Science, 5(3).

Doku, D. T., Acacio-claro, P. J., Koivusilta, L., \& Rimpela, A. (2018). Health and socio-economic circumstances over three generations as predictors of youth unemployment trajectories. 0(0), 1-7. https://doi.org/10.1093/eurpub/cky242

dr Pasha, H. (2021). Labour \& employment in pakistan (pp. 4-141).

Duran, H. E. (2016). Youth unemployment: Macroeconomic causes, consequences and determinants. Plovdiv/BULGARIA, 472.

Eichhorst, W., Boeri, T., Braga, M., De Coen, A., Galasso, V., Kendzia, M. J., Gerard, M., Mayrhuber, C., Pedersen, J. L., Schmidl, R., \& others. (2013). Combining the entry of young people in the labour market with the retention of older workers?: study.

Farooq, S. (2011). The utilisation of education and skills: incidence and determinants among Pakistani graduates. The Pakistan Development Review, 219-244.

Global Employment Trends for Youth 2020 Global Employment Trends for Youth 2020. (2020).

Hafeez, A., Subhan, S., \& Jamil, M. (2020). DETERMINANTS OF UNEMPLOYMENT AMONG EDUCATED YOUTH: A CASE STUDY OF DISTRICT MUZAFFARGARH, PAKISTAN.

Hafeez, E. (2018). Growing Population of Pakistani Youth: A Ticking Time Bomb or a Demographic Dividend. $5(2), 211-226$.

Hällsten, M., Edling, C., \& Rydgren, J. (2016). Social capital, friendship networks, and youth unemployment. Social Science Research. https://doi.org/10.1016/j.ssresearch.2016.06.017

Higgs, J., \& Cherry, N. (2009). Doing qualitative research on practice. In Writing qualitative research on practice (pp. 1-12). Brill Sense.

Hyder, M. (2019). BEHAVIORAL ASPECTS OF YOUTH IN PAKISTAN: UN-EMPLOYMENT AND BEHAVIORAL ASPECTS OF YOUTH IN PAKISTAN : UN-EMPLOYMENT AND ENTREPRENEURSHIP. June.

IMRAN, Z. A. L. I., ASLAM, A., \& CHAUDHARY, M. A. (2020). HUMAN RESOURCE MANAGEMENT, UNEMPLOYMENT AND UNDEREMPLOYMENT IN PAKISTAN. Pakistan Economic and Social Review, 58(2), 181.

Imtiaz, S., Khan, Z., Ullah, M., \& Khan, M. (2020). Determinants of Youth Unemployment in Pakistan. September. https://doi.org/10.32479/ijefi.10386

Inanc, H. (2020). Breaking down the numbers : What does COVID-19 mean for youth unemployment? 1-22.

Jabeen, T. (2011). An Appraisal of Mismatch between Graduating Students Perception and Employers' 
Expectations Regarding Employability Skills. Thesis: University of Gujrat, Pakistan.

Mahmood, T., Ali, A., Akhtar, N., Iqbal, M., Qamar, S., Nazir, H. Z., Abba, N., \& Sana, I. (2014). Determinants of unemployment in Pakistan: A statistical study. International Journal of Asian Social Science, 4(12), 1163-1175.

Maqbool, M. S., Mahmood, T., Sattar, A., \& Bhalli, M. N. (2013). Determinants of unemployment: Empirical evidences from Pakistan. Pakistan Economic and Social Review, 191-208.

Mehmood, K. A., Azam, A., \& Ahmad, A. (2021). Youth Unemployment and its Origins: An Analyses of Multan District.

Mpanju, A. (2012). Employment impact of foreign direct investment. Lap Lambert Academic Publ.

Msigwa, R., \& Kipesha, E. F. (2013). Determinants of youth unemployment in developing countries: Evidences from Tanzania. Journal of Economics and Sustainable Development, 4(14), 67-76.

Nadia Naviwala. (2016). Pakistan's Education Crisis :The Real story. Wilson Center, 01.

Outlook, S. (2021). Trends 2021.

Prof, A., \& Karymshakov, K. (2017). The Education - Job Mismatch Determinants Among Youth of. 66-73.

Saleem, A. (2018). Socio-Psycho Impacts of Unemployment on Educated Youth: A Case Study of Lahore City Socio-Psycho Impacts of Unemployment on Educated Youth : A Case Study of Lahore City.

\section{APPENDIX}

\begin{tabular}{|c|c|c|c|c|c|c|}
\hline \multicolumn{2}{|r|}{$\begin{array}{l}\text { Please select your desired response: For example: If your response is } 4 \text { (Agree) } \\
\text { than it will be like this }\end{array}$} & \multirow[t]{2}{*}{ 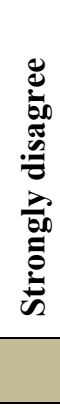 } & \multicolumn{3}{|c|}{$\begin{array}{l}\grave{\Xi} \\
\stackrel{\Xi}{\circlearrowright}\end{array}$} & \multirow[t]{2}{*}{ 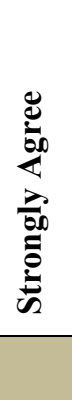 } \\
\hline & Variable 1: Lack of Quality of Education System & & & & & \\
\hline 01 & $\begin{array}{l}\text { Our educational system is responsible for the high unemployment rate } \\
\text { among the educated youth. }\end{array}$ & 1 & 2 & 3 & 4 & 5 \\
\hline 02 & Illiteracy is the cause of your unemployment. & 1 & 2 & 3 & 4 & 5 \\
\hline 03 & Education standard effect on unemployment & 1 & 2 & 3 & 4 & 5 \\
\hline 04 & Low level of education effect on unemployment & 1 & 2 & 3 & 4 & 5 \\
\hline 05 & $\begin{array}{l}\text { Government not taking any step to improve the education system that } \\
\text { causes unemployment. }\end{array}$ & 1 & 2 & 3 & 4 & 5 \\
\hline & Variable 2: Improper Regulation of Government Sector & & & & & \\
\hline 01 & Govt. Is not providing employment opportunities on merit basis. & 1 & 2 & 3 & 4 & 5 \\
\hline 02 & The government is not investing in capital expenditure which creates jobs. & 1 & 2 & 3 & 4 & 5 \\
\hline 03 & $\begin{array}{l}\text { Applying for a government job is only wastage of time and results in } \\
\text { nothing. }\end{array}$ & 1 & 2 & 3 & 4 & 5 \\
\hline 04 & $\begin{array}{l}\text { Government is not providing any scholarship, which is based on earning } \\
\text { purpose. }\end{array}$ & 1 & 2 & 3 & 4 & 5 \\
\hline 05 & Government job need high power of references. & 1 & 2 & 3 & 4 & 5 \\
\hline & Variable 3: Lack of Opportunity & & & & & \\
\hline 01 & Lack of industrial sector causes the lack of opportunity for youth. & 1 & 2 & 3 & 4 & 5 \\
\hline 02 & Government companies give job opportunities on approach basis. & 1 & 2 & 3 & 4 & 5 \\
\hline 03 & Private companies give job opportunity on approach basis. & 1 & 2 & 3 & 4 & 5 \\
\hline 04 & Ignorance of opportunity some time create unemployment & 1 & 2 & 3 & 4 & 5 \\
\hline 05 & lack of money cause lack of opportunity & 1 & 2 & 3 & 4 & 5 \\
\hline & Variable 4: Behavior of People & & & & & \\
\hline 01 & Behavior of people toward low salary effect on unemployment. & 1 & 2 & 3 & 4 & 5 \\
\hline 02 & Behavior of people toward private job effect on unemployment. & 1 & 2 & 3 & 4 & 5 \\
\hline 03 & High educated people prefer high level of job. & 1 & 2 & 3 & 4 & 5 \\
\hline 04 & $\begin{array}{l}\text { High pressure of work changes the behavior of people causes to leave their } \\
\text { job. }\end{array}$ & 1 & 2 & 3 & 4 & 5 \\
\hline 05 & High educated people want high level of facilities . & 1 & 2 & 3 & 4 & 5 \\
\hline
\end{tabular}




\begin{tabular}{|c|c|c|c|c|c|c|}
\hline & Variable 5: Lack of Proper Skills & & & & & \\
\hline 01 & Improper skills causes unemployment. & 1 & 2 & 3 & 4 & 5 \\
\hline 02 & People not get the job in private sector because of low skills. & 1 & 2 & 3 & 4 & 5 \\
\hline 03 & People not get the job in government sectors because of low skills. & 1 & 2 & 3 & 4 & 5 \\
\hline 04 & People not getting quickly that cause unemployment. & 1 & 2 & 3 & 4 & 5 \\
\hline \multirow[t]{2}{*}{05} & Mental health issue creates lack of proper skills & 1 & 2 & 3 & 4 & 5 \\
\hline & Variable 6: Lack of Experience & & & & & \\
\hline 01 & Experience also causes unemployment & 1 & 2 & 3 & 4 & 5 \\
\hline 02 & People not get the job in private sector because of no any experience. & 1 & 2 & 3 & 4 & 5 \\
\hline 03 & People not get the job in government sectors because of no any experience. & 1 & 2 & 3 & 4 & 5 \\
\hline 04 & People not getting job quickly because of lack of experience. & 1 & 2 & 3 & 4 & 5 \\
\hline \multirow[t]{2}{*}{05} & Lack of experience some time creates from health issues. & 1 & 2 & 3 & 4 & 5 \\
\hline & Variable 7: Economic Condition & & & & & \\
\hline 01 & Un stability of economic effect on unemployment & 1 & 2 & 3 & 4 & 5 \\
\hline 02 & Recession effect on unemployment & 1 & 2 & 3 & 4 & 5 \\
\hline 03 & Companies fire their employees because of high inflation. & 1 & 2 & 3 & 4 & 5 \\
\hline 04 & Inflation cause unemployment & 1 & 2 & 3 & 4 & 5 \\
\hline \multirow[t]{2}{*}{05} & Improper regulation of economic condition that cause unemployment.. & 1 & 2 & 3 & 4 & 5 \\
\hline & Variable 8: Unemployment & & & & & \\
\hline 01 & Poor education system causes unemployment. & 1 & 2 & 3 & 4 & 5 \\
\hline 02 & Sometimes government regulation creates unemployment. & 1 & 2 & 3 & 4 & 5 \\
\hline 03 & Recruiter behaviour sometimes causes unemployment. & 1 & 2 & 3 & 4 & 5 \\
\hline 03 & Economic condition causes & 1 & 2 & 3 & 4 & 5 \\
\hline
\end{tabular}

